\title{
УДК: 368.01
}

JEL Classification: G 220

\author{
(C) Кучерівська С.С., Гладчук О.М., 2020 \\ s.kucherivska@chnu.edu.ua, o.gladchuk@chnu.edu.ua \\ Чернівецький національний університет імені Юрія Федьковича, Чернівці
}

\section{ВІТЧИЗНЯНІ РЕАЛІЇ ПЕРЕСТРАХУВАННЯ}

\begin{abstract}
Перестрахування є гарантом та каталізатором розвитку страхового ринку. Нині вітчизняні страховики переважно перестраховують свої ризики в «материнських компаніях» або в іноземних перестраховиків віддаючи майже третину залучених страхових внесків. Вітчизняні страховики беруть до перестрахування $і$ ризики перестрахувальників-нерезидентів, однак ия діяльність ще не настільки успішна.

Серед українських дослідників перестрахування існує термінологічна плутанина щзодо основних аспектів перестрахування. Важливим є розмежування понять перестрахової та перестрахувальної діяльності. Потенційним напрямом подальшого розвитку перестрахування в Украӥні є створення держсавою, чи за ї̈ участі, національної перестрахової компанії або украӥнського перестрахового пулу з використанням сучасних фінансових продуктів та технологічних інновацій.
\end{abstract}

Ключові слова: страхування, перестрахування, перестрахова діяльність, перестраховик, перестрахувальник, перестрахова премія, перестрахова виплата, вхідне перестрахування, вихідне перестрахування, забезпечене перестрахування.

Постановка проблеми. Сучасний стан розвитку вітчизняного страхового ринку характеризується значними регуляторними та цифровими трансформаційними процесами, які спричиняють його подальший інтенсивний розвиток. Деякі 3 актуальних проблем функціонування українських страховиків, такі як: недостатній розмір сформованого капіталу, низький рівень платоспроможності та фінансової безпеки, високий рівень ризикованості страхування окремих великих ризиків, недостатня компетентність персоналу у сфері оцінки страхових ризиків, можна цілком успішно подолати або значно зменшити їхній негативний вплив завдяки системі розвинених перестрахових відносин. Вітчизняне перестрахування, пройшовши складний етап використання в схемних процесах, пов'язаних 3 відмиванням і приховуванням коштів, отриманих незаконним шляхом, під впливом інституційного і законодавчого становлення все більше набуває ознак гаранта стабільності страхового ринку. Проте його потенціал залишається мало задіяним i потребує вдосконалення та подальшого розвитку з урахуванням світових тенденцій та сучасних технологій.

Аналіз останніх досліджень і публікацій. Дослідженням проблем розвитку, суті, механізму здійснення та ролі перестрахування в розвитку страхового ринку займались багато українських і зарубіжних учених. Економічну природу перестрахування, його специфічні ознаки та систематизацію перестрахових відносин досліджували Базилевич В.Д., Внукова Н.М., Кнейслер О.В., Осадець С.С., Третяк К.В., Шумелда Я.П. та інші українські науковці.
Питанням фінансової безпеки, особливостям на проблемам державного регулювання перестрахування в Україні присвятили свої наукові праці Барановський O.I., Фурман B.M., Філонюк О.Ф. Сучасні тенденції розвитку українського перестрахового ринку та проблеми його інтеграції у світовий ринок розглядали Волошина А.П., Козьменко О.В., Нечипорук Л.В., Ткаченко Н.В.

Виділення не розв'язаних раніше частин загальної проблеми. Відзначаючи цінність наукових напрацювань багатьох науковців, відзначимо їх більш теоретичне спрямування без прив 'язки до динамічних умов проведення операцій перестрахування та інформуванням про них вітчизняними компаніями.

Формулювання цілей статті. Метою статті $\epsilon$ впорядкування категорійного апарату та розкриття важливості формування цілісної методологічної бази перестрахової діяльності, дослідження сучасних тенденцій проведення перестрахування в Україні, визначення основних напрямів розв'язання проблем його розвитку.

Виклад основного матеріалу дослідження. Вважаємо за необхідне розпочати 3 розгляду питання чіткості термінології, що використовується при дослідженні перестрахування українськими дослідниками. Якщо законодавчо-нормативні документи однозначні та строгі у використанні термінології, то дослідницька література, в силу можливості застосування синонімів, установлення нових термінів різних явищ $\mathrm{i}$ процесів $\mathrm{y}$ перестрахуванні, розгляду їх з різних сторін, має ширший спектр термінологічних варіацій. Однак вони не завжди є доцільні та обгрунтовані. 
Так, ми можемо сьогодні зустріти на позначення операцій перестрахування одночасно кілька термінів: «перестрахування» «перестраховування» - «перестрахувальна операція», а «перестраховик» досить часто визначається як «перестрахувальна компанія» [1].

Наприклад, Валентина Комадовська у своїх дослідженнях використовує поняття «перестрахувальні послуги» та «перестрахувальні операції» [2]. Кнейслер О.В. вважає, що «на ринку перестрахування інституційними одиницями є страховики, які можуть виступати як перестрахувальники та перестраховики, професійні перестрахувальні компанії та перестрахувальні брокери» [3], а також, що «специфіка перестрахувальної послуги визначається організаційно-правовою природою перестрахової діяльності» [4] i т.п. Тобто використовує терміни «перестрахувальна послуга», «професійні перестрахувальні компанії» та «перестрахувальні послуги» при дослідженні перестрахування.

У результаті такої термінологічної невизначеності та плутанини з'являються такі поняття як «страхувальні поліси» і цілі ланцюжки 3 «перестрахувальних компаній», а також повідомлення на сайтах окремих, добре знаних страховиків, про те, що їхніми основними перестрахувальниками (а не перестраховиками) є General Reinsurance AG, (Gen Re) (Німеччина), SCOR SE (Франція), Polskie Towarzystwo Reasekuracji S.A (Polish Re) (Польща), Lloyd's (Великобританія) та пропозиції скористатися їхнім перестрахувальним захистом [5].

Хотіли б звернути увагу, що Googleперекладач подає некоректний переклад понять перестраховик i перестрахувальник, що i спричиняе помилки при вивченні перестрахування.

В українській мові, як і в російській, є окремі позначення цедент - перестрахувальник i цесіонарій - перестраховик, до того ж закріплені законодавчо (ст. 12 ЗУ «Про страхування»). Наголошуючи на тому, що відносини перестрахування відбуваються лише між страховими компаніями, доречне і використання термінів «первинний страховик» i «перестраховик».

\section{Страхування}
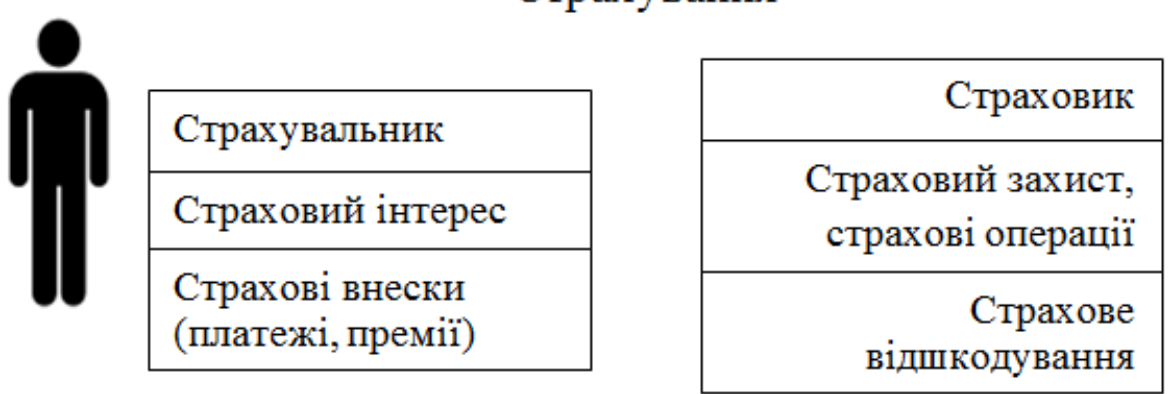

\section{Перестрахування}

(цесія)

\begin{tabular}{|l|l|} 
Сорахова & $\begin{array}{l}\text { Перестрахувальник } \\
\text { (цедент) }\end{array}$ \\
$\begin{array}{l}\text { Відповідальність за } \\
\text { застрахованими } \\
\text { ризиками. } \\
\text { Ризики збитковості }\end{array}$ \\
\cline { 2 - 2 } \\
$\begin{array}{l}\text { Платежі, передані } \\
\text { перестраховикам } \\
\text { (перестрахувальні } \\
\text { платежі) }\end{array}$ \\
\hline
\end{tabular}

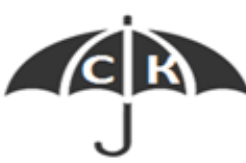

Страхова компанія

Рис.1. Основні поняття операцій страхування і перестрахування (авторська розробка)

Як видно 3 рисунка 1, первинна передача ризику та забезпечення страхового захисту, тобто процес страхування, відбувається страхувальником і страховиком. При цьому 
страхувальник сплачує страхові платежі (премії, внески) та отримує, у разі настання страхового випадку, страхове відшкодування (виплату страхової суми). Операції із забезпечення страхового захисту, тобто страхові операції, здійснює страхова компанія (страховик).

Пошук потрібного страховика, який має ліцензію на проведення належного виду страхування, який надає більш вигідні умови страхового захисту, укладання 3 ним договору i сплата внесків є для страхувальника, особливо юридичної особи, свого роду діяльністю. До того ж, така діяльність також може бути здійснена як в обов язковому порядку, так і на добровільних засадах. Але ж ми не називаємо ці операції вже страхувальними (по аналогії перестрахувальними операціями).

Вторинна і подальша ( $n$-на) передача ризику, забезпечення підтримки первинного страховика відбувається вже в межах перестрахування та ретроцесії. Проте вона відбувається між двома страховими компаніями, одна 3 яких перестрахувальник - передає частину або весь ризик у перестрахування й отримує перестраховий захист від другої страхової компанії - перестраховика, яка вже бере відповідні частки ризиків на перестрахування i гарантує виконання зобов`язань першого страховика, надаючи відповідні фінансові ємності.

Передача ризиків у перестрахування також може відбуватися в обов язковому та добровільному форматах. При цьому, є один нюанс: страхова компанія може передавати певні ризики у перестрахування (тобто бути перестрахувальником), водночас беручи окремі ризики від інших страховиків (тобто виступати перестраховиком). Відповідно, в такої компанії будуть як платежі, які вона сплатила за переданими нею ризиками, так і платежі, які вона отримала за ризиками від інших страховиків. У цьому ракурсі можемо погодитися, що ті платежі, які компанія передає перестраховикам, можна називати перестрахувальними платежами (оскільки вона їх сплачує як перестрахувальник), a ті платежі, які компанія отримує від перестрахувальників - перестраховими платежами (преміями). Наглядовий орган у звітах про стан страхового ринку України зазначає «частки страхових премій, сплачених на перестрахування» і «отримані страхові премії від перестрахувальників». Аналогічно зазначають i «частки виплат, компенсовані перестраховиками», та «частки виплат, компенсовані перестрахувальникам». Зрозуміло, що спеціалізований перестраховик переважно буде мати «отримані перестрахові платежі» та «частки

виплат,

компенсованих

перестрахувальникам».

Оскільки перестраховий захист може бути забезпечений як за конкретним, застрахованим страховиком ризиком, так і за всією діяльністю первинного страховика, i його надає перестраховик, то варто все-таки, говорити про це як про «перестрахові операції» та «перестрахову діяльність».

Відповідно, діяльність первинного страховика, пов язана i 3 зверненням до перестрахової компанії, може називатися «перестрахувальною» і може полягати у:

- формуванні та дотриманні власних правил політики перестрахування;

- контролі за дотриманням вимоги щодо необхідності передачі ризиків у перестрахування;

- пошуку відповідних установленим вимогам перестраховика чи перестрахового брокера 3 належними рівнями фінансової надійності;

- укладанні договору перестрахування із дотриманням усіх його умов;

- реєстрації укладених договорів перестрахування;

- поданні всієї необхідної документації щодо переданих у перестрахування ризиків до Уповноваженого органу;

- виборі інших шляхів забезпечення виконання страхових зобов'язань, крім класичного перестрахування.

Отже, перестрахування виступає ефективним інструментом ризик-менеджменту первинного страховика.

Питання термінологічного

та методологічного висвітлення основ перестрахування важливе ще й з огляду на те, що поступове зростання вітчизняного страхового ринку, збільшення ємності окремих ризиків, ускладнення взаємозв'язків між учасниками ринку при здійсненні ними перестрахових операцій, необхідність відповідати певним міжнародним і національним нормам стали тими вагомими чинниками, що впливають на формування ринку перестрахування в Україні. При цьому успіх цього розвитку багато в чому залежить від належного законодавчого регулювання даної сфери діяльності страховиків.

База спеціального законодавства 3 питань регулювання перестрахової діяльності в Україні представлена такими чинними нормативними актами:

- Законом України «Про страхування», стаття 12 [6].

- Постановою Кабінету Міністрів України від 4 лютого 2004 року №124 «Про затвердження вимог щодо здійснення перестрахування у страховика (перестраховика) нерезидента» [7]. 
- Розпорядженням Національної комісії, що здійснює державне регулювання у сфері ринків фінансових послуг від 15 вересня 2015 року №2201 «Про затвердження Порядку реєстрації договорів перестрахування та надання страховиками (цедентами, перестрахувальниками) інформації про укладені договори перестрахування 3 страховиками (перестраховиками) нерезидентами» [8].

- Розпорядженням Національної комісії, що здійснює державне регулювання у сфері ринків фінансових послуг від 11.07.2013 № 2262 «Про затвердження Вимог до рейтингів фінансової надійності (стійкості) страховиків та перестраховиків-нерезидентів та порядку їх підтвердження та визнання такими, що втратили чинність, деяких розпоряджень Державної комісії з регулювання ринків фінансових послуг України [9].

Статтею 12 ЗУ «Про страхування», крім визначення суті операції перестрахування, його основних учасників, передбачені вимоги щодо їх застосування та фіксації. А саме: «договори перестрахування підлягають обов язковій реєстрації в порядку, затвердженому Уповноваженим органом; перестрахування ризиків у страховиків-нерезидентів здійснюється згідно з вимогами та в порядку, встановленими КМУ; необхідність подання до Уповноваженого органу декларації про ризики та предмет договорів перестрахування, якщо обсяги страхових платежів, що передаються в перестрахування страховикам-нерезидентам, перевищують $50 \%$ ïx загального розміру, отриманого з початку календарного року» [6].

У силу того, що Уповноважений наглядовий орган відповідає за моніторинг фінансового стану страхових i перестрахових компаній i зацікавлений у стабільності розвитку страхового ринку, основна увага в даних документах приділена інформуванню наглядового органу страховиками (перестрахувальниками) про наявність укладених договорів перестрахування, рейтинг фінансової надійності та статус перестраховиків, 3 якими співпрацюють страховики.

Тобто регламентована діяльність універсальних страхових компаній, які звертаються за перестраховим захистом і також можуть здійснювати операції перестрахування. Водночас відсутне ліцензування перестрахової діяльності, не визначені умови функціонування спеціалізованих страховиків, а саме: додаткового забезпечення платоспроможності та фінансової стійкості. Законодавство не передбачає регламентації основних моментів операцій перестрахування (методи перестрахування, види договорів, порядок розрахунку платежів переданих перестраховикам, облік комісії, тощо), а їхня чітка фіксація важлива ще й з огляду на те, що вони можуть бути використані у різних незаконних цілях.

Зауважимо, що в планах НБУ як нового наглядового органу за страховими компаніями $\epsilon$ запровадження ліцензування перестрахової діяльності як виняткового виду діяльності спеціалізованого перестраховика і встановлення відповідних нормативів [10].

Попит на перестрахові послуги визначається рівнем фінансового забезпечення та платоспроможності перестрахувальника. Недостатньо капіталізовані страховики, 3 низьким рівнем фінансового забезпечення не мають змоги самостійно утримувати кумулятивні або значні за розміром ризики, що і зумовлює необхідність їх перестрахування.

За даними Нацкомфінпослуг, в Україні за станом на 01.01.2020 працювало 233 страхових компанії, 3 них лайфових - 23 компанії, ризикового страхування - 210 компаній. У 2015 р. всього на вітчизняному ринку працювало 361 компанія, у тому числі 49 лайфових страховиків та 312 - нон-лайфових [11]. Відповідно за цей період загальна кількість страховиків зменшилася на 128 компаній, або $35,46 \%$. Найбільше зменшилася кількість лайфових страховиків - на 26 компаній, або у 2 рази. Кількість нон-лайфових страховиків зменшилася на 32,7\%, тобто 102 компанії залишили ринок за період 2015-2019 pр.

Iз 63 страхових/перестрахових брокеріврезидентів і 20 брокерів-нерезидентів станом на початок 2020 р. намір провадити посередницьку діяльність на території України 3 укладення договорів страхування/перестрахування i 3 страховиком-нерезидентом заявили лише 3 брокери, з них один брокер-резидент.

Основна частина діючих на страховому ринку України страховиків або перестраховують ризики в «материнських компаніях», або через брокерів чи безпосередньо в іноземних перестраховиків, або ведуть неактивну страхову діяльність у межах власних фінансових можливостей.

Серед 49 компаній, представлених у рейтингу Форіншурер, «Рейтинг страхових компаній за розміром капіталу» за 9 місяців 2020 р. перші 9 страховиків мають власний капітал більше 300 млн. грн. (найбільше - ARX - 894 млн. грн., найменше у цій групі - Альфа-страхування - 305 млн. грн.). Другу групу складають страховики із середніми фінансовими можливостями із власним капіталом в межах 100-300 млн. грн. (19 страховиків), і третя група - 18 компаній, у яких власний капітал лишень трохи більший за 
мінімальний розмір статутного капіталу для нонлайфових страховиків [12].

Згідно із статистичними даними Нацкомфінпослуг, за договорами перестрахування ризиків за 2019 рік українські страховики-цеденти сплатили 16713,4 млн. грн. часток страхових премій, з яких:

- перестраховикам-нерезидентам - 3298,2 млн. грн., що на 10,0\% більше порівняно $з 2018$ роком (за 2018 рік - 2997,5 млн. грн.) та на 768 млн. грн. (30,35\%) більше, ніж у 2015 р.

- перестраховикам-резидентам - 13415,2 млн. грн., що на 10,2\% менше порівняно з відповідним показником 2018 року (за 2018 рік - 14943,2 млн. грн.), але на 6034,1 млн. грн. більше, ніж у 2015 році.

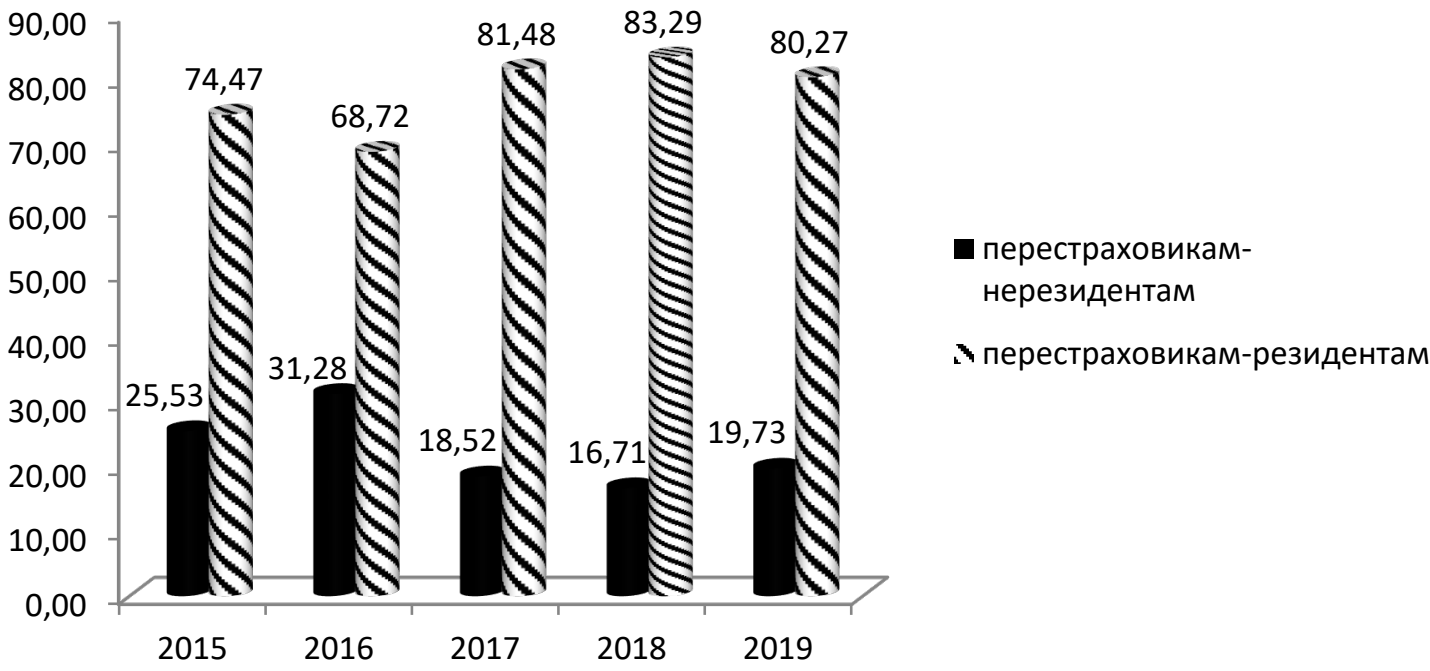

Рис. 2. Структура вихідного перестрахування в Україні за 2015-2019 рр., у \% [11]

Як бачимо 3 рис. 2, страховики України в період 2015-2019 pp. в основному перестраховували ризики у вітчизняних перестраховиків. Відповідно 75\% і більше (за винятком 2016 р.) страхових премій за договорами перестрахування було передано перестраховикамрезидентам. Цьому сприяли простіші законодавчі умови передачі ризиків у перестрахування у перестраховика-резидента.

Співвідношення вихідного перестрахування до валових страхових премій станом на 31.12.2019 складало 31,5\%, що на 4,8 в.п. менше аналогічного показника 2018 року, на 10,7 в.п. менше показника 2017 року і на 1,8 в.п. менше за показник 2015 p.

Табличя 1

\section{Структура вихідного перестрахування за видами страхування за період 2015-2019 рр., млн. грн., [11]}

\begin{tabular}{|c|c|c|c|c|c|}
\hline Показники & 2015 & 2016 & 2017 & 2018 & 2019 \\
\hline страхування майна & 1798,7 & 2273,9 & 3172,9 & 3771,3 & 3679,1 \\
\hline $\begin{array}{l}\text { страхування від вогневих } \text { ризиків } \\
\text { ризиків стихійних явищ }\end{array}$ & 871,6 & 1066,8 & 2280,1 & 2772,3 & 2870,0 \\
\hline страхування фінансових ризиків & 1712,7 & 2013,2 & 3954,9 & 3617,2 & 2396,5 \\
\hline страхування вантажів та багажу & 2376,0 & 3484,7 & 3887,5 & 1538,8 & 1535,2 \\
\hline страхування наземного транспорту & 544,6 & 720,7 & 904,1 & 1273,8 & 1401,3 \\
\hline $\begin{array}{ll}\text { страхування відповідальності } & \text { перед } \\
\text { третіми особами } & \end{array}$ & 1052,8 & 1032,6 & 1634,8 & 1221,9 & 1034,1 \\
\hline $\begin{array}{l}\text { страхування цивільної відповідальності } \\
\text { власників транспортних засобів }\end{array}$ & 461,5 & 586,3 & 586,0 & 640,0 & 904,2 \\
\hline
\end{tabular}

Якщо розглянути структуру вихідного перестрахування за видами страхування (табл. 1), то видно, що вітчизняні страховики найбільше передавали у перестрахування ризики за договорами страхування майна, страхування фінансових ризиків, страхування від вогневих ризиків і страхування вантажобагажу. Частка цих ризиків за період 2015-2019 рр. у різні роки варіювалася в межах від 11 до 26\%. 
Ризики за видами особистого страхування, страхування життя, медичного та інших, не представлених у таблиці, видів страхування складали незначний відсоток упродовж аналізованого періоду.

При цьому частка страхових виплат, компенсованих перестраховиками, у сумі валових страхових виплат впродовж періоду мала зростаючу тенденцію і становила у 2017 р. 11,47\% а в 2019 р. вже $17,5 \%$.
Із даних таблиці 2 видно, що у 2019 р. загальна сума часток страхових виплат, компенсованих перестраховиками, складала 2508,2 млн. грн., що на 1162,4 млн. грн. (або 86,37\%) більше, ніж на початку аналізованого періоду. У тому числі перестраховиками-нерезидентами було компенсовано 2210,4 млн. грн., що на 9,0\% більше в порівнянні з 2018 роком, а перестраховикамирезидентами - лише 297,8 млн. грн., що на $30,9 \%$ менше в порівнянні 3 відповідним показником 2018 року.

\section{Суми часток страхових виплат, компенсованих перестраховиками в Україні}

Таблиия 2 за період 2015-2019 pp. [11]

\begin{tabular}{|c|r|r|r|r|r|}
\hline Показник & \multicolumn{1}{c|}{$\mathbf{2 0 1 5}$} & \multicolumn{1}{c|}{$\mathbf{2 0 1 6}$} & $\mathbf{2 0 1 7}$ & $\mathbf{2 0 1 8}$ & $\mathbf{2 0 1 9}$ \\
\hline $\begin{array}{l}\text { Загальна сума часток страхових виплат, } \\
\text { компенсованих перестраховиками, млн грн. }\end{array}$ & 1345,8 & 1233,2 & 1208,2 & 2459,0 & 2508,2 \\
\hline Всього у\% & 100 & 100 & 100 & 100 & 100 \\
\hline у т.ч перестраховиками-нерезидентами, млн грн. & 848,1 & 954,7 & 928,2 & 2028,2 & 2210,4 \\
\hline частка у загальній сумі, \% & 63,02 & 77,42 & 76,83 & 82,48 & 88,13 \\
\hline перестраховиками-резидентами, млн грн. & 497,7 & 278,5 & 280,0 & 430,8 & 297,8 \\
\hline частка у загальній сумі, \% & 36,98 & 22,58 & 23,17 & 17,52 & 11,87 \\
\hline
\end{tabular}

Тобто основна частка виплат за договорами перестрахування в період 2015-2019 pp. припадала на перестраховиків-нерезидентів. До того ж частка участі у виплатах перестраховиківрезидентів упродовж аналізовано періоду мала спадну тенденцію. Так, у 2015 p. перестраховиками-резидентами було сплачено майже $37 \%$ усіх виплат, за договорами перестрахування, а в 2019 р. - лише $11,87 \%$.

Якщо розглядати структуру перестрахування у нерезидентів у географічному розрізі (табл. 3), то побачимо, що в більшості випадків вітчизняні страховики впродовж 2015-2019 рр. зверталися за перестраховим захистом до цесіонаріїв 3 Швейцарії, Великобританії, Німеччини, Польщі, Австрії. Інші країни мали змінний характер участі, що зумовлено вимогами до фінансової стійкості перестраховиків, законодавчими обмеженнями щодо країни-агресора, співпрацею з відповідними брокерами та специфікою ризиків, що передавалися в перестрахування.

Таблиия 3

Структура перестрахування у нерезидентів за країнами, у \% від загальної суми переданих платежів за період 2015-2019 pp. [11]

\begin{tabular}{|l|r|r|r|r|r|}
\hline \multicolumn{1}{|c|}{ показники } & \multicolumn{1}{c|}{$\mathbf{2 0 1 5}$} & \multicolumn{1}{c|}{$\mathbf{2 0 1 6}$} & \multicolumn{1}{c|}{$\mathbf{2 0 1 7}$} & \multicolumn{1}{c|}{$\mathbf{2 0 1 8}$} & \multicolumn{1}{c|}{$\mathbf{2 0 1 9}$} \\
\hline Німеччина & 18,1 & 10,5 & 10,3 & 18,6 & 22,3 \\
\hline Великобританія & 24,5 & 16,5 & 15,5 & 23,7 & 17,3 \\
\hline Австрія & 5,6 & 4,7 & 7,1 & 8,5 & 19,4 \\
\hline Польща & 8,5 & 8,6 & 9,7 & 12,4 & 10,0 \\
\hline Швейцарія & 10,9 & 7,6 & 16,9 & 10,6 & 7,0 \\
\hline Франція & 3,9 & - & 2,8 & 5,0 & 6,0 \\
\hline США & 5,8 & 3,8 & 2,9 & 4,2 & 3,6 \\
\hline Італія & - & - & - & 1,4 & 1,8 \\
\hline Ірландія & 2,1 & - & - & - & 1,4 \\
\hline Чехія & 1,5 & - & - & 2,4 & 3,3 \\
\hline Індія & - & 8,9 & 3,8 & 1,5 & - \\
\hline Китай & - & 12,3 & 4,3 & - & - \\
\hline Малайзія & - & 7,0 & 6,7 & - & - \\
\hline Республіка Корея & - & 5,5 & - & - & - \\
\hline Литва & 2,6 & - & - & - & - \\
\hline Російська Федерація & 7,2 & 3,3 & 5,3 & 2,3 & - \\
\hline Інші країни & 9,3 & 11,5 & 14,7 & 9,2 & 7,9 \\
\hline
\end{tabular}




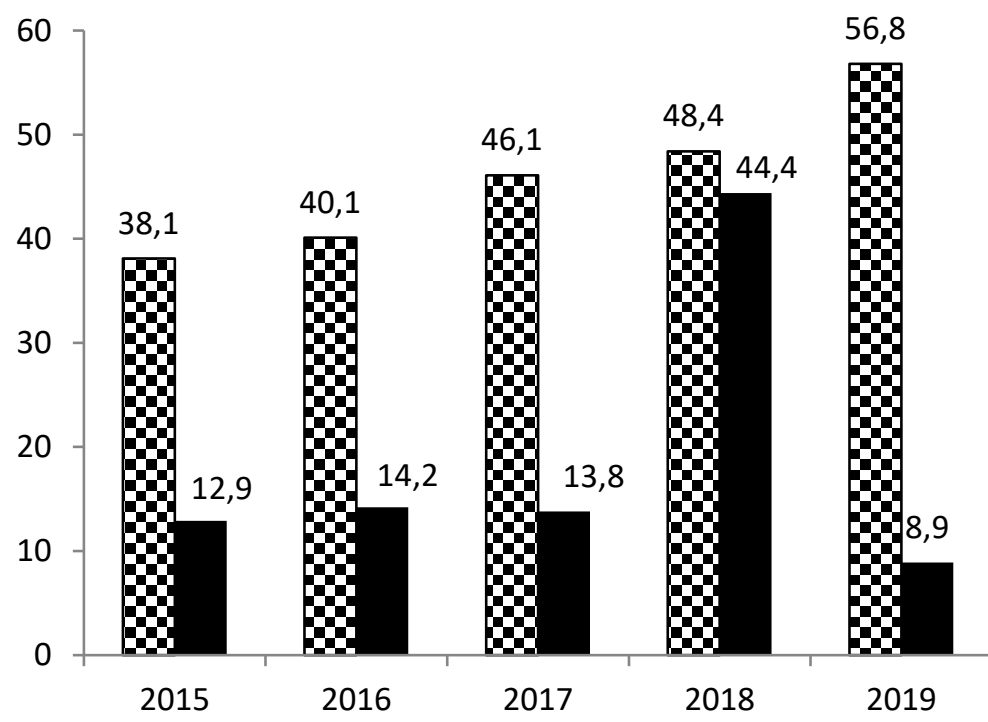

\section{口отримані страхові премії від перестрахувальників- нерезидентів}

- Виплати, компенсовані перестрахувальникамнерезидентам

Рис. 3. Показники вхідного перестрахування страхового ринку України за 2015-2019 рр. (млн. грн.) [11]

Водночас вітчизняні страхові компанії також виступали у ролі перестраховиків, забезпечуючи перестрахове покриття перестрахувальникамнерезидентам (Рис. 3).

Як видно 3 рис. 3, упродовж аналізованого періоду спостерігалася позитивна тенденція збільшення отриманих вітчизняними перестраховиками премій за договорами перестрахування. Збільшення склало 18,7 млн. грн. (з 38,1 млн. грн. у 2015 р. до 56,8 млн. грн. у 2019 р.), тобто приріст склав 49,08\%. Але виплати, компенсовані перестрахувальникамнерезидентам, були незначними, за винятком
2018 р., коли виплати майже дорівнювали отриманим преміям. Відповідно рівень виплат за договорами вхідного перестрахування складав 33,9\% у 2015 р., 91,7\% - у 2018 р. та 15,7\% - у 2019 p. (Рисунок 4).

Варто звернути увагу на більш виважений підхід до вибору ризиків на перестрахування вітчизняними перестраховиками в аналізованому періоді порівняно з періодом 2010-2014 рр., коли рівень виплат за вхідним перестрахуванням складав відповідно 955,33\%, 134,70\%, 38,24\%, $8,45 \%$ та $76,74 \%$ [11].

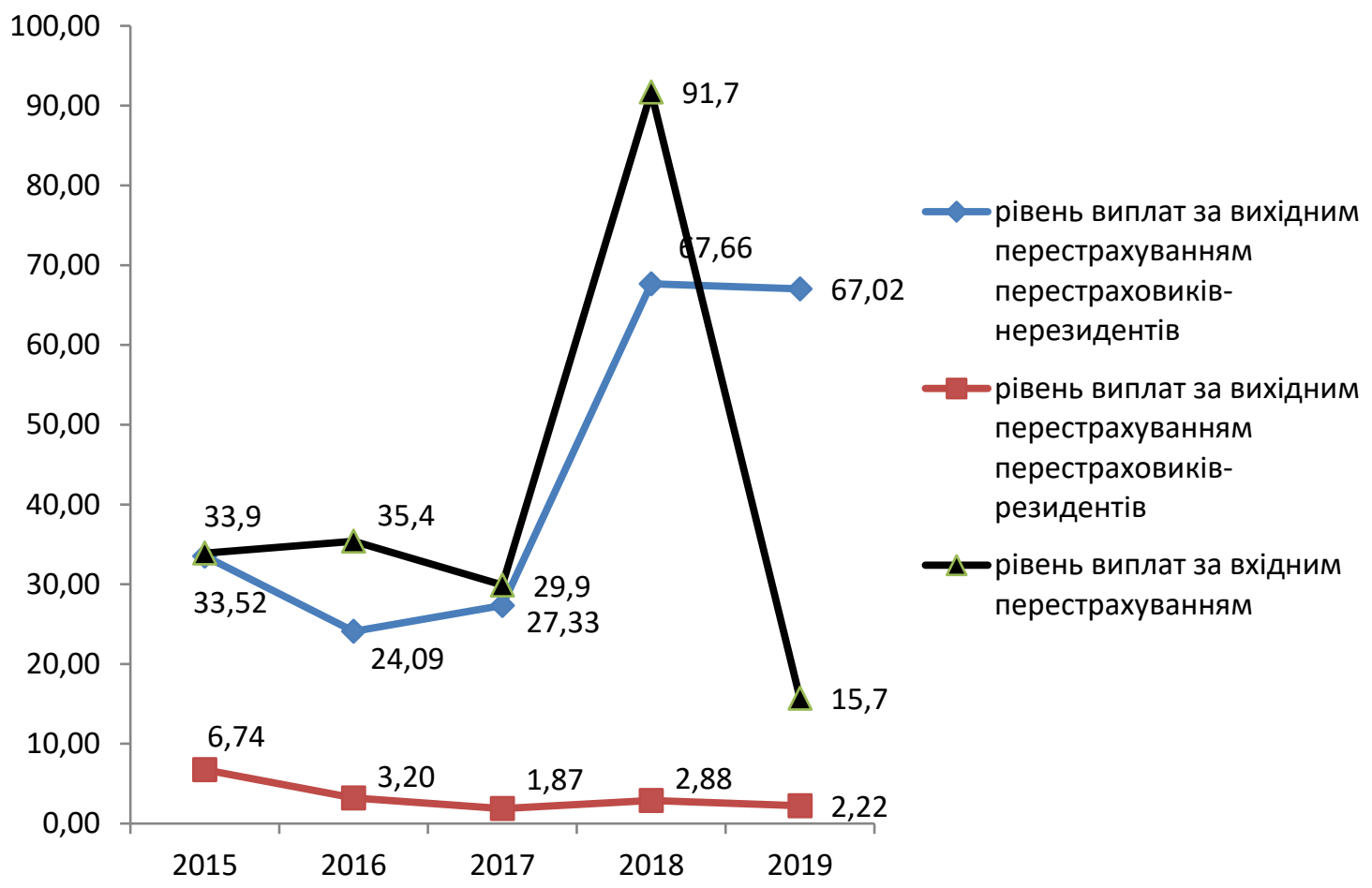

Рис. 4. Рівні виплат за вхідним і вихідним перестрахуванням в Україні за період 2015-2019 рр., \% (сформовано за даними [11]) 
При цьому рівень виплат за вихідним перестрахуванням, наприклад у 2019 р. склав лише $15,01 \%$ (13,58\% у 2015р.).

3 цього можна зробити висновок про важливість розкриття i дослідження саме діяльності перестраховиків.

Зауважимо, що детальної інформації про ризики, які вітчизняні страхові компанії брали на відповідальність за договорами перестрахування, немає. А цьому також варто приділяти увагу 3 огляду на збалансування портфелів ризиків i можливого розвитку саме діяльності спеціалізованих перестраховиків.

Як бачимо, роль ринку перестрахування в Україні поступово зростає. Основна частка ризиків перестраховується на внутрішньому ринку, вітчизняні страховики все частіше виступають у ролі перестраховиків i для страховиків-резидентів і нерезидентів.

На сьогодні у світі діє близько 350 професійних перестраховиків, з яких у Свропі 132. Функціонують національні перестраховики в Польщі (Polish Re), Словенії (Triglav Re, Sava Re), у Боснії та Герцеговині (Bosna Re), у Латвії (Riga $\mathrm{Re})$, у Болгарії діє три перестраховика, у Румунії - 8 компаній перестрахування. Це, у певній мірі, підтримує невеликі національні страхові компанії, здешевшує вартість перестрахування, а отже і страхування.

За даними S\&P Global Raitings, серед 20 найбільших перестраховиків світу за показниками чистої перестрахової премї, крім класичних, відомих перестраховиків, є перестрахові компанії Індії, Кореї, Іспанії, Канади (Таблиця 4).

Табличья 4

Tоп 20 світових перестраховиків у 2019 р. за даними S\&P Global [13]

\begin{tabular}{|l|l|c|}
\hline \multicolumn{1}{|c|}{ № } & \multicolumn{1}{|c|}{ Назва перестраховика } & $\begin{array}{c}\text { Сума чистих перестрахових } \\
\text { премій у 2019 р., млрд. дол. } \\
\text { США }\end{array}$ \\
\hline 1. & Swiss Re & 39,65 \\
\hline 2. & Munich Re & 35,39 \\
\hline 3. & Hannover Rueck Se & 22,82 \\
\hline 4. & Berkshire Hathaway & 16,95 \\
\hline 5. & SCORE RE & 16,20 \\
\hline 6. & China Reinsurance Corp. & 12,24 \\
\hline 7. & Reinsurance Group America Inc. & 11,30 \\
\hline 8. & Lloyd's & 10,54 \\
\hline 9. & Everest Re Group Ltd & 7,82 \\
\hline 10. & Partner Re & 6,91 \\
\hline 11. & General Insurance Corp. of India & 6,21 \\
\hline 12. & MS\&AD Insurance Group Holdings & 5,62 \\
\hline 13. & Korean Reinsurance Co & 4,79 \\
\hline 14. & Transatlantic Holdings & 4,50 \\
\hline 15. & Sompo Holdings & 4,03 \\
\hline 16. & MapfreRe & 3,72 \\
\hline 17. & R+V Versicherung & 3,64 \\
\hline 18. & RenaissanceRe Holdings & 3,38 \\
\hline 19. & Axis Capital Holdings & 3,28 \\
\hline 20. & Fairfax Financial Holdings & 3,12 \\
\hline
\end{tabular}

До 2008 р. в Україні функціонувало декілька спеціалізованих перестраховиків, зокрема «Гарант PЕ», «ЦЕСIЯ», «VAB RE», пізніше «Лідер РЕ» та інші. Однак на сьогодні «чистих» перестраховиків на українському ринку немає. Вітчизняні страховики передають ризики між собою або звертаються до іноземних та світових перестраховиків.

Зі зміною державного органу, уповноваженого здійснювати нагляд за діяльністю страхових компаній в Україні, можна очікувати на дієві зміни у сфері перестрахування 3 урахуванням світового досвіду. Зокрема необхідне:
- запровадження ліцензування перестрахової діяльності 3 визначенням основних категорій договорів перестрахування;

- створення або участь держави у створенні національної перестрахової компанії;

- розробка та запровадження стратегії розвитку страхового ринку i сфери перестрахування, зокрема;

- запровадження положень Solvency II, за допомогою яких підвищиться реальний рівень перестрахових операцій.

Багатьма науковцями й експертами страхової сфери розглядаються питання щодо можливості створення спільної перестрахової ємності для 
надійного перестрахування ризиків в Україні, зокрема створення українського перестрахового пулу. Звісно, в історії становлення та розвитку українського ринку страхування відомі факти щодо невдалих спроб створення пулів, але були й вдалі їх реалізації.

Основним ініціатором створення перестрахового пулу в Україні виступає Асоціація «Страховий бізнес» (АСБ), активним учасником якої є СК «ЕКСПО СТРАХУВАННЯ». Відповідно пропонується дві моделі такого пулу:

1) «модель із загальною ємністю серед учасників АСБ за найбільш поширеними договорами i подальшим перестрахуванням перевищення обсягу («пул») за кордоном;

2) модель 3 перестрахуванням однотипних ризиків компаній Асоціації як «оптового клієнта» безпосередньо в іноземного перестраховика через брокера 3 вигідними тарифами як для набагато більшого обсягу, ніж може передавати будь-яка страхова компанія індивідуально» [14].

Противники ідеї створення державної перестрахової компанії наголошують на тому, що у випадку недостатньої фінансової потужності така організація буде задіяна лише на внутрішньому ринку, що не принесе особливої користі ринку. Тож діяльність державного перестраховика повинна бути зорієнтована на роботу і на зовнішніх регіональних ринках, що можливе при належному кадровому та фінансовому забезпеченні, використанні сучасних фінансових продуктів.

Серед сучасних можливостей забезпечення перестрахового захисту без наявності відповідного фінансового рейтингу $\epsilon$ застосування так званого «забезпеченого перестрахування» (Collateralized Reinsurance) [15].

Забезпечене перестрахування може бути надане як традиційне перестрахування, яке захищає «загальний чистий збиток» (UNL), або як «гарантія збитків у галузі» (ILW), яке останнім часом більш поширене.

Забезпечене перестрахування відноситься до договору або програми перестрахування, які повністю забезпечені, як правило, інвесторами або стороннім капіталом. Даний інструмент виступає простою альтернативою рейтинговому балансу перестрахування. Для проведення операції перестрахування перестраховик, який не має відповідного міжнародного рейтингу, повинен надати перестрахувальнику поліс перестрахування й інвестиційний продукт, який дає можливість інвестору по-перше, внести відповідний заставний капітал, по-друге, повернути інвестору капітал і премії по ньому при закінченні терміну перестрахування.
При забезпеченому перестрахуванні укладається тристороння угода між цедентом, цесіонарієм та фінансовою установою (банком, хедж-фондом, ін.) про наявність коштів на випадок виникнення зобов язань 3 відшкодування збитків. Отже, щоб іноземний страховик передав ризики в перестрахування до України, український перестраховик повинен відкрити рахунок в іноземному банку на суму взятої відповідальності 3 прив язкою до конкретного договору перестрахування, який виступає гарантією платоспроможності для іноземного страховика. Іноземна компаніяперестрахувальник має право скористатися коштами такого рахунку для покриття збитків за договором перестрахування. А український перестраховик отримує свою плату за перестрахований ризик.

Дана операція хоч i має значний мінус, зокрема для України (це переведення значних коштів за кордон), однак має суттєві тенденції до зростання. На основі темпів зростання забезпеченого перестрахування за останні кілька років на рівні 23-25\% експерти прогнозують поступове витіснення класичного перестрахування забезпеченим, до того ж воно вимагає набагато менших витрат. Також наголосимо на появі продуктів FinTech та InsurTech, які надають ширші можливості на ринках капіталу.

При виході на зарубіжний ринок українським перестраховикам необхідно враховувати, що збитковість страхових операцій у перші роки буде свідомо вищою, ніж у локальних перестраховиків. 3 одного боку, стандартні відрахування 3 премії, що припадають на комісії цедента i «ланцюжка» брокерів, що доводять зарубіжний ризик до перестраховика, складають від 10 до $30 \%$. 3 іншого, новий невеликий перестраховик, що не має високого міжнародного рейтингу, не зможе відразу отримати доступ до всього спектра ризиків. Таким перестраховикам доведеться покривати спочатку ті ризики, від яких 3 тих чи інших причин відмовилися глобальні компанії або ті, на які вони можуть запропонувати меншу, ніж конкуренти, ціну. Лише 3 перебігом часу, заробивши репутацію на ринку і підтвердивши виплатами якість сервісу, новий перестраховик отримує шанс брати участь у справді прибуткових класах бізнесу.

\section{Висновки:}

1. Важливим аспектом належного розвитку ринку перестрахування в Україні $\epsilon$ чітке законодавче затвердження i дотримання категорійного апарату перестрахової діяльності. При цьому варто розмежовувати перестрахову i перестрахувальну діяльність. 
2. Уповноваженому наглядовому органу необхідно зосередити увагу і на особливостях діяльності перестраховиків (ліцензування, вимоги i нормативи діяльності), а не лише перестрахувальників. Це може стати поштовхом до створення потужних внутрішніх перестраховиків.

3. На сьогодні вітчизняні страхові компанії переважно (більше 75\%) перестраховують ризики у перестраховиків-резидентів. В основному це ризики майнового страхування, страхування фінансових ризиків і відповідальності перед третіми особами. Однак виплати за договорами перестрахування українські страховики отримують переважно від перестраховиківнерезидентів.
4. Вітчизняні
страховики
відповідально
ставляться до
досить вибору

перестраховиків-нерезидентів. Як правило, це перестраховики з високим рейтингом фінансової надійності 3 Австрії $(19,4 \%$ усіх переданих платежів), Німеччини (22,3\%), Франції (6,0\%), Великобританії (17,3\%), Швейцарії $(7,0 \%)$, Польщі $(10,0 \%)$.

5. Водночас вітчизняні страхові компанії також виступали у ролі перестраховиків, забезпечуючи перестрахове покриття перестрахувальникам-нерезидентам. При цьому рівень виплат за договорами вхідного перестрахування був на порядок вищий, ніж за вихідним перестрахуванням.

6. Подальшими науковими розвідками у цьому напрямі будуть питання створення національної перестрахової компанії (пулу) та сучасні методи активізації її діяльності.

\section{Список літератури}

1. Поплавська О. Управління якістю в Кельнському, Мюнхенському і Швейцарському перестраховому товаристві. Страховий клуб КНЕУ. URL: http://pck.kneu.edu.ua/?p=189 (дата останнього звернення: 25.12.2020).

2. Комадовська В. Необхідність здійснення перестрахувальних операцій та управління ними при страхуванні життя. Ринок ичінних паперів України. 2011. №3-4. С. 9-14.

3. Кнейслер О.В. Ринок перестрахування України: теоретико-методологічні домінанти формування та пріоритети розвитку: монографія. К.: Центр учбової літератури, 2012. 416с.

4. Кнейслер О.В. Ідентифікація перестрахувальної послуги у системі страхових відносин. Фінансовий nростір. 2013. № 3 (11). С. 152-155.

5. Перестрахування. Наші партнери. Офіційний сайт СK «Універсальна». URL : https://universalna.com/pro-kompaniyu/nashipartneri/perestrahuvannya/ (дата останнього звернення: 25.12.2020).

6. Про страхування : Закон України від 07.03.1996 p. № 85/96-ВР / Верховна Рада України. URL : https://zakon.rada.gov.ua/laws/show/85/96-

$\% \mathrm{D} 0 \% \mathrm{~B} 2 \% \mathrm{D} 1 \% 80 \#$ Text (дата останнього звернення: 25.12.2020).

7. Про затвердження вимог щодо здійснення перестрахування у страховика (перестраховика) нерезидента : Постанова Кабінету Міністрів України від 4 лютого 2004 р. №124 / Кабінет Міністрів України. URL : https://zakon.rada.gov.ua/laws/show/124-2004$\% \mathrm{D} 0 \% \mathrm{BF}$ Tехt (дата останнього звернення: 25.12.2020).

8. Про затвердження Порядку реєстрації договорів перестрахування та надання страховиками (цедентами, перестрахувальниками) інформації про укладені договори перестрахування 3 страховиками (перестраховиками) нерезидентами : Розпорядження Національної комісії, що здійснює державне регулювання у сфері ринків фінансових послуг від 15 вересня 2015 року № 2201 / Національна комісія, що здійснює державне регулювання у сфері ринків фінансових послуг. URL : https://zakon.rada.gov.ua/laws/show/z1327-15\#Text (дата останнього звернення: 25.12.2020).

9. Про затвердження Вимог до рейтингів фінансової надійності (стійкості) страховиків та перестраховиків-нерезидентів та порядку їх підтвердження та визнання такими, що втратили чинність, деяких розпоряджень Державної комісії 3 регулювання ринків фінансових послуг України : Розпорядженням Національної комісії, що здійснює державне регулювання у сфері ринків фінансових послуг від 11.07.2013 № 2262/ Національна комісія, що здійснює державне регулювання у сфері ринків фінансових послуг. URL https://zakon.rada.gov.ua/laws/show/z1285-13\#Text (дата останнього звернення: 25.12.2020).

10. Біла книга «Майбутнє регулювання ринку страхування в Україні». Національний банк України. URL:

https://bank.gov.ua/admin_uploads/article/White_paper_i nsurance_pr_2020-04-30.pdf? v=4 (дата звернення: 25.12.2020).

11. Інформація про стан i розвиток страхового ринку України. Інформаційні матеріали Національної комісії, щчо здійснює державне регулювання на фінансовому ринку. URL: https://www.nfp.gov.ua/ua/Informatsiia-pro-stan-irozvytok-strakhovoho-rynku-Ukrainy.html (дата останнього звернення: 25.12.2020).

12. Рейтинг страхових компаній України. Форіншурер страхування. https://forinsurer.com/ratings/nonlife/20/9/2 (дата останнього звернення: 25.12.2020).

13. Top 20 global reinsurers of 2020. PropertyCasualty360: Property \& Casualty Insurance. URL:

https://www.propertycasualty360.com/2020/09/29/top-

20-global-reinsurers-of-2020/?slreturn $=20201128131635$ (дата останнього звернення: 15.12.2020). 
14. Можливості створення Перестрахового Пулу України. Офіційний сайт страхової компанії «ЕКСПО СТРАХУВАННЯ».

URL:

https://exposk.com.ua/news/novyny-strakhovoho-

rynku/insurance-pool.html (дата останнього звернення:
25.12.2020)

15. Guy Carpenter explains 'Collateralized Reinsurance'. Insurance journal. URL: https://www.insurancejournal.com/news/international/201 5/02/12/357276.htm (дата останнього звернення: 25.12.2020).

\section{References}

1. Poplavska, O. "Quality management in the Cologne, Munich and Swiss Reinsurance Companies", Strakhovyi klub KNEU, available at: http://pck.kneu.edu.ua/?p=189, (Accessed 25 December 2020).

2. Komadovska, V. (2011), "The need for reinsurance operations and their management in life insurance", Rynok tsinnykh paperiv Ukrainy, no. 3-4, pp. 9-14.

3. Kneisler, O.V. (2012), Rynok perestrakhuvannia Ukrainy: teoretyko-metodolohichni dominanty formuvannia ta priorytety rozvytku [Reinsurance market of Ukraine: theoretical and methodological dominants of formation and development priorities], Tsentr uchbovoi literatury, Kyiv, $416 \mathrm{p}$.

4. Kneisler, O.V. (2013), "Identification of reinsurance service in the system of insurance relations", Finansovyi prostir, no. 3 (11), pp. 152-155.

5. Ofitsiinyi sait SK "Universalna", "Reinsurance, Our partners", available at: https:/universalna.com/prokompaniyu/nashi-partneri/perestrahuvannya/, (Accessed 25 December 2020).

6. Law of Ukraine, “On Insurance” from 07.03.1996 No 85/96-BP, available at: https://zakon.rada.gov.ua/laws/show/79-20\#Text, (Accessed 25 December 2020).

7. Resolution of the Cabinet of Ministers of Ukraine, "On approval of requirements for reinsurance by a nonresident insurer (reinsurer)" from 04.02.2004 No 85/96BP, available at: https://zakon.rada.gov.ua/laws/show/1242004-\%D0\%BF\#Text, (Accessed 25 December 2020).

8. Order of the National Commission for State Regulation of Financial Services Markets, "On approval of the Procedure for registration of reinsurance agreements and provision by insurers (assignors, reinsurers) of information on concluded reinsurance agreements with insurers (reinsurers) by non-residents" from 15.09.2015 No 2201, available at: https://zakon.rada.gov.ua/laws/show/z1327-15\#Text, (Accessed 25 December 2020).

9. Order of the National Commission for State Regulation of Financial Services Markets, “ On approval of the Requirements to ratings of financial reliability (stability) of non-resident insurers and reinsurers and the procedure for their confirmation and recognition as invalid, some orders of the State Commission for Regulation of Financial Services Markets of Ukraine" from 11.07.2013 No 2262, available at: https://zakon.rada.gov.ua/laws/show/z1285-13\#Text, (Accessed 25 December 2020).

10. Bila knyha, "Future regulation of the insurance market in Ukraine", National Bank of Ukraine, available at:

https://bank.gov.ua/admin_uploads/article/White_paper_i nsurance_pr_2020-04-30.pdf?v $=4, \quad$ (Accessed $\overline{25}$ December 2020).

11. Information on the state and development of the insurance market of Ukraine, Informatsiini materialy Natsionalnoi komisii, shcho zdiisniuie derzhavne rehuliuvannia na finansovomu rynku, available at: https://www.nfp.gov.ua/ua/Informatsiia-pro-stan-i-

rozvytok-strakhovoho-rynku-Ukrainy.html, (Accessed 25 December 2020).

12. "Rating of insurance companies of Ukraine", Forinshurer strakhuvannia, available at: https://forinsurer.com/ratings/nonlife/20/9/2, (Accessed 25 December 2020).

13. Top 20 global reinsurers of 2020, PropertyCasualty360: Property \& Casualty Insurance, available

https://www.propertycasualty360.com/2020/09/29/top-

20-global-reinsurers-of-2020/?slreturn=20201128131635, (Accessed 25 December 2020).

14. "Possibilities of creating a Reinsurance Pool of Ukraine", Ofitsiinyi sait strakhovoi kompanii "EKSPO STRAKhUVANNIa", available at: https://exposk.com.ua/news/novyny-strakhovohorynku/insurance-pool.html, (Accessed 25 December 2020).

15. "Guy Carpenter explains 'Collateralized Reinsurance", Insurance journal, available at: https://www.insurancejournal.com/news/international/201 5/02/12/357276.htm, (Accessed 25 December 2020).

Аннотация

София Кучеривская, Ольга Гладчук

\section{ОТЕЧЕСТВЕННЫЕ РЕАЛИИ ПЕРЕСТРАХОВАНИЕ}

Перестрахование является гарантом и катализатором развития страхового рынка. Сейчас отечественные страховщики преимущественно перестраховывают свои риски в «материнских компаниях» или в иностранных перестраховщиков, отдавая почти треть привлеченных страховых взносов. Отечественные страховщики принимают в перестрахование и риски перестраховщиков-нерезидентов, однако эта деятельность еще не настолько успешна.

Среди украинских исследователей перестрахования существует терминологическая путаница относительно основных аспектов перестрахования. Важным является разграничение понятий перестраховочной и перестраховательной деятельности. Потенциальным направлением дальнейшего развития 
перестрахования в Украине является создание государством, или с ее участием, наџиональной перестраховочной компании или украинского перестраховочного пула с использованием современных финансовых продуктов и технологических инноваџий.

Ключевые слова: страхование, перестрахование, перестраховочная деятельность, перестраховщик, перестрахователь, перестраховочная премия, перестраховочная выплата, входящее перестрахование, исходное перестрахования, обеспеченое перестрахование.

\section{Summary}

Sofiia Kucherivska, Olha Hladchuk

\section{DOMESTIC REALITIES OF REINSURANCE}

Reinsurance is a guarantor and catalyst for the development of the insurance market, it increases its capacity and financial security.

The aim of the article is to study the current trends of reinsurance in Ukraine, identify the main problems in their implementation and formulate appropriate areas for their solution.

The works of domestic and foreign scientists in the field of reinsurance have become a theoretical and informational basis for writing the article. This study was conducted by implementing methods of analysis and synthesis, theoretical generalization, comparative analysis, statistical and graphical methods.

There is no single approach among Ukrainian reinsurance researchers regarding the use of basic reinsurance terms. It is important to use the correct reinsurance terminology, which is clearly defined in Ukrainian legislation, distinguishing between the concepts of "actions of the primary reinsurer" and "actions of the reinsurer" in reinsurance. At present, domestic insurers mostly reinsure their risks in "parent companies" or foreign reinsurers, paying almost a third of the reinsurance premiums involved. Ukrainian reinsurance is characterized by the fact that reinsurance premiums are paid mainly to resident reinsurers, while the majority of insurance payments are made by non-resident reinsurers. Domestic insurers are reinsuring the risks of primary non-resident insurers, but this activity is not yet so successful. A potential direction for the further development of reinsurance in Ukraine is the creation by the state, or with its participation, of a national reinsurance company or a Ukrainian reinsurance pool using modern financial products and technological innovations. As a result of the transfer of powers to supervise the activities of insurers to the NBU, we can expect effective changes in the legislative provision of insurance and reinsurance activities based on world experience, implementation of Solvency II and improving the quality of insurance and reinsurance activities by insurance market participants.

Key words: insurance, reinsurance, reinsurance activity, reinsurer, assignor, reinsurance premium, reinsurance payment, active reinsurance, passive reinsurance, collateralized reinsurance. 